\title{
Wybrane problemy badań miejsca pracy w systemie wartości
}

\section{Wprowadzenie} $\bigvee$ / badaniach socjologicznych występuje szereg ujęć problematyki miejsca cyjnie badań poświęconych zagadnieniom wartości pracy dla jednostek i grup społecznych. Powiązanie w koncepcji badawczej kategorii: praca i wartości posiada charakterystyczne walory poznawcze, lecz jednocześnie wzmacnia dylematy natury teoretycznej i metodologicznej, które są specyficzne dla każdej z nich rozpatrywanej jako przedmiot badań. Podjęte w opracowaniu rozważania dotyczą wybranych problemów występujących w tego rodzaju eksploracjach badawczych. Kryterium doboru stanowią z jednej strony ujęcia zastosowane w badaniach własnych, z drugiej natomiast omówienia tych zagadnień w dorobku naukowym Jana Szymczyka. Szczególną uwagę zwrócono na te poglądy, które odnoszą się do roli wartości w perspektywie procesów kształtowania życia społecznego, ich funkcji jako podstaw realizowania się „świata społecznego”, tworzenia więzi międzyludzkich, ale też podziałów społecznych. Analizowanie systemu wartości jest traktowane jako jeden z najbardziej znaczących nurtów badań nad życiem społecznym i świadomością ${ }^{1}$. Dokonane przez autora pogłębione studia teorii wartości i wykorzystania różnych koncepcji w badaniach socjologicznych dostarczają

* Dr hab. Jagoda Jezior - Katedra Socjologii Gospodarki i Metod Badań Społecznych, Uniwersytet Marii Curie-Skłodowskiej, e-mail: jagoda.jezior@mail.umcs.pl, ORCID: 0000-0003-3357-8821.

1 J. Szymczyk, Pomiędzy marzeniami a faktami. Szkice socjologiczne, Norbertinum, Lublin 2005, s. 134. 
złożonej argumentacji natury poznawczej, wpisując się równocześnie w dyskusje na temat procesu rozwoju socjologii jako dyscypliny naukowo-badawczej. Dla celów artykułu z tego obszernego zbioru wybrano elementy krytycznej analizy, refleksje teoretyczne i metodologiczne w zakresie stosowanych podejść badawczych oraz implikacje związane $z$ badaniami empirycznymi.

Rozważane zagadnienia zostały ujęte w trzech aspektach: teoretycznym, metodologicznym i empirycznym. Pierwszy dotyczy sposobów definiowania pojęć pracy i wartości, relacji między tymi kategoriami w koncepcji badań sytuacji pracy jednostek, a na tym tle sposobów określania miejsca pracy w systemie wartości. Drugi odnosi się do charakterystycznych podejść występujących w badaniach wartości, w tym obejmujących procedury opisu systemów wartości i tworzenia skal, rozwiązania operacyjne i techniczne przyjmowane w badaniach ilościowych, zasady analizy porównawczej. Trzeci aspekt to ustalenia wynikające z praktyki badawczej oraz ich egzemplifikacja. Materiał empiryczny pochodzi z projektów (badania sondażowe) zrealizowanych w latach 1996-2019 na terenie województwa lubelskiego.

Początek wskazanego cyklu wiąże się z udziałem autorki w badaniach zespołowych „Kapitał ludzki czynnikiem rozwoju Euroregionu Bug”, wykonanych w 1996 r. na terenie regionu środkowowschodniej Polski². W opracowaniu zostanie uwzględniona próba podstawowa, losowa (dalej: MR). W ramach złożonego przedmiotu badań znalazło się też zagadnienie wartości pracy ${ }^{3}$. Kolejne projekty (indywidualne) dotyczyły szeroko rozumianej sytuacji pracy jednostek posiadających różny status zatrudnienia. W skład zbioru wchodzą badania pracowników najemnych, którymi w 2004 r. objęto 359 respondentów, głównie z powiatu bialskiego (dalej: PN). Pozostałe projekty skierowano do osób prowadzących samodzielną działalność gospodarczą $\mathrm{w}$ skali mikroprzedsiębiorstw ${ }^{4}$. W pierwszym, zrealizowanym w latach 2002-2003, próba liczyła 739 respondentów. Po modyfikacji koncepcji badania powtórzono w latach: 2011 (615) i 2019 (340). $\mathrm{W}$ tych trzech projektach, które w tekście będą oznaczane odpowiednio jako: P1, P2 i P3, próby zostały przygotowane przez Urząd Statystyczny w Lublinie. Zastosowane techniki to: wywiad kwestionariuszowy, ankieta roznoszona, CAWI. Koncepcje badawcze zbudowano na podobnych podstawach teoretycznych

${ }^{2}$ Badania stanowiły część interdyscyplinarnego projektu: Euroregion BUG. Kierował nimi prof. dr hab. Leon Dyczewski OFM Conv, Katolicki Uniwersytet Lubelski. Teren badań pokrywał się zasadniczo z obecnym województwem lubelskim. Wywiady kwestionariuszowe przeprowadzono w dwóch próbach: losowej (803 respondentów) i celowej (204). Efektem była m.in. publikacja L. Dyczewski, Społeczno-kulturowe czynniki rozwoju regionu środkowo-wschodniej Polski i Euroregionu Bug, Norbertinum, Lublin 1997.

${ }^{3}$ Zob. J. Jezior, Wartość pracy. Studium socjologiczne na podstawie badań mieszkańców regionu środkowowschodniej Polski, Wydawnictwo UMCS, Lublin 2005.

${ }^{4}$ W badaniach wzięli też udział właściciele małych firm (10-49 osób pracujących), ale ich liczba była niewielka. 
i metodologicznych, a mimo swoistości przedmiotu i problematyki ważną część każdej z tych koncepcji stanowiła tematyka miejsca pracy w systemie wartości i ogólnie wartości pracy. Projekty różni jednak czas realizacji, charakter zbiorowości, struktury cech demograficznych i społeczno-zawodowych. Jednym z tego przejawów jest udział badanych posiadających wyższe wykształcenie: $\mathrm{MR}-10,3 \%$; PN - 49,6\%; P1 - 29,5\%; P2 - 51,8\%; P3 - 83,6\%. Wielowymiarowa dyferencjacja dotyczy także respondentów prowadzących działalność gospodarczą. Na przykład, badaniami objęto zarówno mikropracodawów, jak i osoby samozatrudnione, w rozumieniu działalności tzw. solo, bez zatrudniania dodatkowych pracowników (odsetki w próbach: P1 - 36,6\%; P2 - 54,3\%; P3 - 68,1\%). W literaturze polskiej i zagranicznej przedstawia się liczne problemy badań pracy na własny rachunek ${ }^{5}$. Odnoszą się one do dyskusji na temat istoty i definicji samozatrudnienia ${ }^{6}$, zastosowań teorii przedsiębiorcy i przedsiębiorczości ${ }^{7}$, statusu zatrudnienia i zasad funkcjonowania jednostek na rynku pracy $^{8}$, znaczenia jednoosobowej działalności dla rozwoju gospodarki i rozwiązywania kwestii bezrobocia, jak również trudności realizacji badań porównawczych, zwłaszcza międzynarodowych? Niespełnienie warunków reprezentatywności (oprócz MR) i wspomniane różnice między projektami powodują ograniczenia na poziomie porównywania wyników badań oraz ich ekstrapolacji. Niemniej replikacja wskaźników umożliwia opis $i$ analizę krytyczną fragmentów uzyskanych rezultatów. Celem tego postępowania jest poszukiwanie odpowiedzi na pytanie o miejsce pracy w systemie wartości, ale też o wartość pracy dla jednostek, uwzględniając kryteria wartościowania tej sfery (poziom ogólny) i aspekty określające satysfakcjonującą pracę (poziom wykonywanej pracy). Podjęte zadania obejmują wymiar merytoryczny i metodologiczny, w tym problemy poznawcze badań sondażowych.

\section{Praca i sytuacja pracy - zagadnienia definicyjne}

W badaniach poświęconych problematyce pracy ludzkiej i jej miejsca w systemie wartości występuje wiele tradycji teoretycznych i podejść badawczych.

${ }^{5}$ Por. Praca na własny rachunek - determinanty i implikacje, red. E. Kryńska, IPiSS, Warszawa 2007.

${ }^{6} \mathrm{~J}$. Wiśniewski, Istota samozatrudnienia, „Studia z Zakresu Prawa, Administracji i Zarządzania” 2013 , t. 3 , s. 41.

7 J.W. Carland, F. Hoy, W.R. Boulton, J.A.C. Carland, Differentiating Entrepreneurs from Small Business Owners. A Conceptualization, w: Entrepreneurship. Concepts, Theory and Perspective, red. Á. Cuervo, D. Ribeiro, S. Roig, Springer-Verlag, Berlin 2007, s. 79, https://www.uv.es/catedrabancajauveg/docs/LibroCuervoRibeiroRoigENG (dostęp: 3.07.2021).

${ }^{8}$ A.R. Thurik, M.A. Carree, A.J. van Stel, D.B. Audretsch, Does Self-Employment Reduce Unemployment? „Journal of Business Venturing” 2007, t. 23, nr 6, s. 674.

9 S.M. Lee, S.J. Peterson, Culture, Entrepreneurial Orientation, and Global Competitiveness, „Journal of World Business” 2000, t. 35, nr 4, s. 405. 
Leon Dyczewski, podkreślając podmiotowy i sensotwórczy charakter pracy, jej znaczenie dla rozwoju jednostek i powiązanie form pracy z dążeniem do zaspokajania potrzeb, wskazuje wymiary: więziotwórczy, konieczności, obowiązku, twórczości ${ }^{10}$. Janusz Mariański akcentuje szczególną rolę pracy zarówno na płaszczyźnie indywidualnej (źródło dojrzewania, środek pozwalający na odkrywanie pełni człowieczeństwa, szansa poznania własnych możliwości oraz ich aktualizacji), jak i społecznej (tworzenie dobra społeczeństwa, działanie na rzecz innych). Jako powiązane $\mathrm{z}$ tą sferą istotne warunki podaje samorealizację i poczucie sensu w codziennym życiu ${ }^{11}$. Przegląd koncepcji socjologicznych dowodzi ogólnej zbieżności poglądów na temat zasadniczych wymiarów pracy, do których należą: społeczny, kulturowy, aksjologiczny, moralny, religijny, więziotwórczy, samorealizacyjny, wychowawczy, ekonomiczny, socjalno-bytowy, polityczny.

W literaturze odnoszącej się do ujęć pracy na gruncie socjologii wskazuje się na występowanie charakterystycznych aspektów społecznych, w tym organizacyjnych i stratyfikacyjnych, dotyczących społecznego podziału pracy i realizacji ról społeczno-zawodowych, z uwzględnieniem wymiaru kulturowe$\mathrm{go}^{12}$. Urszula Swadźba podkreśla dominację dwóch zasadniczych elementów: rzeczowego i czynnościowego, z przewagą drugiego z nich jako przedmiotu badań ${ }^{13}$. Krzysztof Konecki zwraca zaś uwagę na praktykę badawczą: tendencję określania pracy jako zespołu czynności prowadzących do wytwarzania wartości materialnych i niematerialnych, ale też mieszanie podejść oraz słabe rozpoznanie aspektów czynnościowych i treściowych, wynikające ze stosowanej metodologii ${ }^{14}$. Mimo podobieństw schematów definicje pracy różnią się zakresem i sposobami wyjaśniania poszczególnych elementów. Punktem wyjścia będzie zatem definicja Jana Szczepańskiego, który pod pojęciem pracy rozumie: „(...) każdą celową czynność prowadzącą do zaspokajania dowolnych potrzeb ludzkich, posiadającą społeczną doniosłość (...), zapewniającą jednostkom lub grupom, które ją wykonują określoną pozycję w społeczeństwie"15. Definicja ma ogólny charakter, ale jej autor dodatkowo wyróżnia implikacje: praca to świadome, planowe, ukierunkowane na cel działanie; celem jest zaspokojenie różnych potrzeb (np. biologicznych, kulturalnych, ekonomicznych); praca ma społeczny charakter, wymaga współpracy i kierowania, różne jej rodzaje mają

${ }^{10}$ L. Dyczewski, Kultura polska w procesie przemian, TN KUL, Lublin 1993, s. 16 n.

${ }_{11}$ J. Mariański, Etos pracy bezrobotnych (raport z badań empirycznych), TN KUL, Lublin 1994, s. 41.

${ }^{12}$ H. Januszek, J. Sikora, Socjologia pracy, Wydawnictwo Akademii Ekonomicznej, Poznań 1998, s. $10-11$.

${ }^{13}$ U. Swadźba, Śląski etos pracy. Studium socjologiczne, Wydawnictwo UŚ, Katowice 2001, s. 21.

${ }^{14}$ K. Konecki, Praca $w$ koncepcji socjologii interakcjonistycznej, „Studia Socjologiczne” 1988, nr 1(108), s. 240-241.

${ }_{15} \mathrm{~J}$. Szczepański, Uwagi o przedmiocie i zadaniach socjologii pracy, w: Jak pracuje człowiek. Z badań polskich psychologów, socjologów i ekonomistów, red. B. Biegeleisen-Żelazowski, T. Tomaszewski, A. Sarapata, J. Rosner, Książka i Wiedza, Warszawa 1961, s. 171. 
zaspokajać potrzeby, podlegają kontroli i regulacji społecznej; metody i środki realizacji celów są wyznaczane przez strukturę i kulturę grup; znaczenie pracy wiąże się z zaspokajaniem ważnych dla społeczeństwa potrzeb (np. uznania); rodzaj pracy decyduje o pozycji jednostki w strukturze społecznej ${ }^{16}$.

$\mathrm{W}$ badaniach własnych, poświęconych sytuacji pracy jednostek posiadających różny status zatrudnienia, zastosowano dwojakie ujęcie przedmiotowej kategorii. Wąskie koncentruje się na cechach i warunkach wykonywanej pracy. Do zakresu szerszej definicji włączono - za Krystyną Janicką - subiektywne nastawienia i oceny: orientacje, postrzeganie własnej roli zawodowej, satysfakcję. W tym ujęciu praca jest traktowana jako element systemu wartości ${ }^{17}$. Uwzględniono ponadto wartości łączone z pracą (cele, oczekiwania). W rezultacie ważną część koncepcji stanowią kryteria wartościowania i oceniania pracy, w tym orientacje wartościujące, a także ich wpływ na decyzje i działania w sferze pracy ${ }^{18}$. Praca zawodowa została natomiast określona jako świadome działanie skierowane na realizację zadań i tworzenie wartości (materialnych i niematerialnych), oparte na wiedzy i umiejętnościach wynikających z posiadanego wykształcenia oraz przygotowania zawodowego, polegające na wykorzystywaniu środków i wykonywaniu czynności związanych z treścią i charakterem danej profesji, stanowiące podstawę ekonomicznego utrzymania. Wyróżniają ją cechy: celowość, systematyczność, trwałość i spójność, realizacja na podstawie wiedzy i kwalifikacji nabytych formalnie i/lub w toku praktyki, a także funkcje: dochodowa, społeczna, samorealizacyjna, stratyfikacyjna i prestiżowa ${ }^{19}$.

Z perspektywy badań sytuacji pracy jednostek i miejsca pracy w systemie wartości istotne znaczenie mają również problemy, które współcześnie łączą się ze zmianami rynku pracy, społecznego podziału pracy i modelu pracy, oddziałując też na podejścia badawcze. Szczególna rola przypada przeobrażeniom $\mathrm{w}$ zakresie treści i form pracy, systemu zatrudnienia, rzeczywistej roli pracy w realizowaniu wartości ekonomicznych i pozaekonomicznych oraz funkcji stratyfikacyjnej. W literaturze podkreśla się wpływ kierunków przemian społecznych, w tym dotyczących formowania cech społeczeństwa postindustrialnego

16 Tamże, s. 172-173.

17 K. Janicka, Sytuacja pracy a struktura społeczna. W poszukiwaniu nowego wymiaru pozycji społeczno-zawodowej, Wydawnictwo IFiS PAN, Warszawa 1997, s. 17-18, 21.

18 Celem konstruowania orientacji na wartości (wartościujących) było m.in.: uchwycenie kryteriów decydujących o znaczeniu pracy, podstaw działania, konsekwencji przekonań; redukcja danych i zwiększenie trafności pomiaru. Po raz pierwszy te zmienne złożone, których budowa opierała się na bateriach wskaźników, zastosowano w badaniach z 1996 r. (MR). W badaniach osób prowadzących działalność gospodarczą były to orientacje: samorealizacyjna, ekonomiczna, profesjonalna, merytokratyczna, przedsiębiorcza, społeczna (więziotwórcza). Zob. J. Jezior, Społeczno-kulturowe i rynkowe czynniki kształtowania sytuacji pracy przedsiębiorców. Na podstawie badań małych firm w województwie lubelskim, Wydawnictwo UMCS, Lublin 2009, s. 78-87, 333-362.

19 Por. tamże, s. 61-63. 
i informacyjnego, co implikuje pytania o rodzaj przewartościowań w sferze pracy, ale też o modyfikację sposobów jej rozumienia i wzrost wieloznaczności samego terminu ${ }^{20}$. Analizuje się zasady funkcjonowania różnych podmiotów rynku pracy oraz formy pracy, zwłaszcza w kontekście rozwoju nowoczesnych technologii telekomunikacyjnych i „kapitalizmu informatycznego", przejawy transformacji tradycyjnych społeczeństw pracy w społeczeństwa wiedzy ${ }^{21}$. Kolejne zagadnienie to konsekwencje procesów deregulacji rynku pracy, upowszechnianie się elastycznych form zatrudnienia i zmiany modelu pracy zarobkowej, wpływające jednocześnie na postawy wobec pracy ${ }^{22}$. Charakterystyczne problemy społeczne i zarazem obszary eksploracji wiążą się ponadto z obecnością różnych pokoleń na rynku pracy. Z jednej strony wymaga to rozwiązywania kwestii szczególnej sytuacji ludzi młodych, w tym niepewności ekonomicznej i tymczasowości pracy jako jej współczesnych wyznaczników ${ }^{23}$. Z drugiej strony są to potrzeby redefiniowania aktywności zawodowej starszych pokoleń i możliwości wykorzystania ich potencjału na rynku pracy, uwzględniając chociażby skutki procesów demograficznych. Oznacza to konieczność projektowania strategii polityki zatrudnienia i polityki rynku pracy ${ }^{24}$, co przyczynia się do zmian instytucji życia społecznego, ale też ich recepcji. Wreszcie obecne przeobrażenia pracy można rozpatrywać w odniesieniu do dyskusji na temat renesansu subdyscypliny: socjologia pracy w Polsce. Akcentuje się wagę tych zmian, które podważają wyznaczane dotychczas granice pracy, typu: materialna i niematerialna, produkcyjna i reprodukcyjna, formalna i nieformalna, standardowe i niestandardowe formy zatrudnienia, a także podziały między sferą pracy i życiem osobistym ${ }^{25}$. Na obraz pracy i sposoby jej badania wpływają ponadto takie zjawiska jak: narastanie skali problemu zaburzenia równowagi między pracą i życiem pozazawodowym oraz postępująca segmentacja rynku pracy ${ }^{26}$. Poza wszystkim przywołuje się dylematy metodologiczne i poznawcze łączące się ze stosowaniem badań ilościowych, a zarazem zalecenia realizacji

${ }^{20}$ D. Walczak-Duraj, Miejsce pracy w systemie wartości. Wyzwania wynikające z rozwoju technologii cyfrowych, „Zeszyty Naukowe KUL” 2019, t. 62, nr 4(248), s. 94.

${ }^{21}$ F. Bylok, U. Swadźba, D. Walczak-Duraj, Praca i konsumpcja w perspektywie tworzenia ładu aksjonormatywnego, Wydawnictwo Naukowe „Śląsk”, Katowice 2017, s. 58-59.

${ }_{22}$ M. Szylko-Skoczny, Zmiany w modelu pracy, „Studia Ekonomiczne” 2014, nr 167, s. 175-176.

${ }^{23}$ A. Kiersztyn, Niepewność zatrudnienia młodych dorosłych. Analiza sekwencji karier zawodowych, „Studia BAS” 2020, nr 2(62), s. 74.

${ }^{24}$ B. Urbaniak, Polityka państwa wobec osób starszych na rynku pracy, „Problemy Polityki Społecznej. Studia i Dyskusje” 2016, nr 34(3), s. 79.

${ }^{25}$ E. Giermanowska, A. Mrozowicki, J. Róg-Ilnicka, Socjologia pracy w Polsce. Społeczno-gospodarcze i polityczne problemy instytucjonalizacji subdyscypliny, „Przegląd Socjologiczny” 2019, t. 68, nr 3, s. 33-34.

${ }^{26}$ S. Borkowska, Równowaga między praca a życiem pozazawodowym, „Acta Universitatis Lodziensis. Folia Oeconomica" 2010, nr 240, s. 17, 26. 
pogłębionych badań jakościowych, pozwalających trafniej opisać zmieniający się zakres znaczeniowy pojęcia praca, wykraczający poza dotychczas dominujący paradygmat ${ }^{27}$.

\section{Praca jako wartość w ujęciach badawczych}

W badaniach dotyczących problematyki miejsca pracy w systemie wartości zazwyczaj występuje założenie, nawet jeśli nie jest wyrażone explicite, że praca stanowi wartość. O wiele trudniej jest znaleźć odpowiedzi na pytania: co to znaczy, że praca jest wartością, jakiego rodzaju jest to wartość, jakie jest jej usytuowanie w systemie wartości i jakie kryteria o tym decydują. Wśród złożonych wyborów koncepcyjnych znajdują się kwestie typu: ustalenie obiektu oceny czy wartościowania, wskazanie mechanizmów i kryteriów procesu wartościowania, operacjonalizacja, określenie znaczenia stosowanych metod badawczych.

Jeżeli chodzi o obiekt wartościowania, to ważne jest rozróżnienie kategorii: praca w sensie ogólnym i konkretna praca. Władysław Piwowarski - na gruncie teorii postaw - definiuje pracę w sensie ogólnym (ang. work) jako całokształt działalności jednostki w procesie społecznego wytwarzania dóbr, jako pewną wartość społeczną ugruntowaną w celach życiowych i hierarchii wartości. Pozostaje ona w relacji nadrzędności wobec sposobu postrzegania pracy zawodowej, inaczej zajęcia (ang. job), zespołu czynności aktualnie wykonywanych ${ }^{28}$. Rozróżnienie to jest bardziej czytelne w konstrukcjach teoretycznych niż na poziomie operacjonalizacji i pomiaru, ponieważ niełatwo je uchwycić w odpowiedziach na pytania kwestionariuszowe. Niemniej sama ta koncepcja posiada walory analityczne, co wykorzystano także w badaniach własnych.

W ramach podejść badawczych zwraca się ponadto uwagę na różne ujęcia kryteriów procesu wartościowania. Tadeusz Kiecka-Niechajowicz wymienia dwa szczególne aspekty: przedmiotowy (oceny zjawisk, faktów, procesów społecznych) i metodologiczny (ocena procedur badawczych w socjologii). $\mathrm{W}$ pierwszym wypadku rolę kryteriów pełnią wartości, w drugim natomiast kwestie formalne: standardy i logika postępowania badawczego ${ }^{29}$.

Pierwszy z podanych aspektów przywołuje problem koncepcji wartości oraz ich badania na gruncie socjologii. Maria Misztal podkreśla przypisywanie wartościom centralnego miejsca w systemie przekonań jednostek, trwałości

${ }^{27}$ D. Walczak-Duraj, Miejsce pracy w systemie wartości..., s. 94-95.

28 W. Piwowarski, Postawy religijne a postawy wobec pracy, w: Człowiek i praca. Studia i szkice wokół chrześcijańskiej koncepcji pracy, red. J. Wołkowski, Instytut Wydawniczy „Pax”, Warszawa 1979, s. 308.

29 T. Kiecka-Niechajowicz, Kryteria wartościowania w socjologii a kryteria społecznej efektywności pracy, w: Socjologiczne mierniki efektywności pracy, red. W. Jacher, Wydawnictwo UŚ, Katowice 1985, s. $120-122$. 
i nadrzędności w stosunku do postaw, wymiaru normatywnego, a także funkcji kryteriów dokonywanych wyborów ${ }^{30}$. J. Szymczyk, analizując możliwości dokonania względnie zintegrowanego oglądu zróżnicowanych postaw wobec wartości, odwołuje się do perspektywy relacjonistycznej. Wskazuje sposoby rozumienia wartości, które są: ujmowane jako istniejące w przedmiotach materialnych i niematerialnych (rozumienie przedmiotowe); utożsamiane z działaniami i związane z samą relacją dokonującą się pomiędzy podmiotem a przedmiotem (rozumienie „pośrednie”); sytuowane jako kategorie aksjologiczne w doświadczeniu jednostek (rozumienie podmiotowe) ${ }^{31}$. Zdaniem autora tę perspektywę można uznać za „(...) próbę poszukiwania kompromisu między zwolennikami subiektywnego i obiektywnego statusu wartości. Wartość jest bowiem wynikiem relacji doznającego i aktywnego podmiotu wobec pewnych przedmiotów (obiektów)"32. Akcentuje on jednocześnie znaczenie aplikacyjne tego podejścia badawczego, jak również szczególnie cenne dla socjologów atrybuty, jakimi są możliwości eksplorowania i analizy „(...) faktycznych, a nie tylko deklarowanych werbalnie, zachowań i działań podmiotów funkcjonujących w sieci różnych relacji” ${ }^{33}$.

Rozumienie wartości jako określonego rodzaju przekonań, które wywierają wpływ na wybór celów i środków działania, jest łączone głównie z dorobkiem Clyde’a Kluckhohna ${ }^{34}$. Socjologowie zazwyczaj zwracają uwagę na kontekst badawczy tego dominującego podejścia. Zdaniem M. Misztal dwojakie traktowanie wartości jako przedmiotów i/lub przekonań ma znaczenie metodologiczne i wiąże się z warunkami technicznymi badań empirycznych. Ujęcie wartości jako stanów psychicznych przekłada się też na specyficzne nurty badań „postaw wartościujących” i „orientacji wartościujących" ${ }^{35}$. T. Kiecka-Niechajowicz podkreśla trudności operacjonalizacji, ale i wspomniane możliwości techniczne, co uznaje zresztą za przyczynę przewagi ujęć dotyczących manifestowania się wartości w życiu społecznym nad pytaniami o to, „jak wartości istnieją ${ }^{36}$. Hanna Świda-Zięba proponuje traktować „rzeczywistość wartości” w kategoriach „rzeczywistości bytów" wykreowanych przez procesy wartościowania. Z perspektywy doświadczeń badawczych zauważa zawikłanie sporu: na ile „kwalifikacja bytów” wynika z właściwości podmiotowych (typu upodobania), a na ile $\mathrm{z}$ atrybutów tych bytów ${ }^{37}$. Stefan Nowak, odnosząc się do procesu wartościowania, uznaje

${ }^{30}$ M. Misztal, Problematyka wartości w socjologii, PWN, Warszawa 1980, s. 104-107.

${ }^{31}$ J. Szymczyk, Socjologiczne rozumienie wartości w aspekcie relacjonistycznym, „Zeszyty Naukowe KUL” 2019, t. 62, nr 3(247), s. 40-41.

${ }^{32}$ Tamże, s. 38.

33 Tamże, s. 52.

${ }^{34}$ A. Kłoskowska, Socjologia kultury, PWN, Warszawa 1983, s. 188.

${ }^{35}$ M. Misztal, Problematyka wartości w socjologii..., s. 67.

${ }^{36}$ T. Kiecka-Niechajowicz, Kryteria wartościowania..., s. 122.

${ }^{37}$ H. Świda-Zięba, Wartości egzystencjalne młodzieży lat dziewięćdziesiątych, Wydawnictwo UW, Warszawa 1999, s. 9. 
je - obok wiedzy - za rodzaj przeżyć czy nastawień związanych z jednostką oraz jej sytuacją w świecie społecznym i przyrodniczym. Wartościowanie wskazuje więc na sposób, w jaki jednostki postrzegają i oceniają poszczególne elementy sytuacyjne, wpływa też na zachowania ${ }^{38}$. J. Szymczyk akcentuje natomiast potrzebę rozgraniczania terminów: wartościowanie i ocenianie. Wartościowanie traktuje jako nierozdzielne z pojęciem wartości i uświadomieniem sobie istoty konkretnej wartości zrealizowanej w przedmiocie. Preferencyjne porządkowanie oznacza czynność „względem czegos””: ludzi, zdarzeń, innych wartości. Ocenianie zaś to ujęcie wartości w aspekcie zewnętrznego wzorca, hierarchii czy skali. Wynikiem preferencyjnego oceniania może być tworzenie hierarchii wartości ${ }^{39}$. Komentując problemy definiowania wartości, taksonomii i możliwości poznania, autor podkreśla występowanie analogicznych trudności w przypadku wielu pojęć socjologicznych. Proponuje zatem koncentrować się na funkcjonowaniu wartości w życiu społecznym, ich znaczeniu jako przedmiotu dążeń i działań, ale też - refleksji. Uwydatnia zarazem aspekt metodologiczny tego ujęcia, pisząc: „Niezależnie od poglądów, wartości ciągle pozostają w polu zainteresowania szczególnie tych, którzy zmierzają do wyjaśnienia przemian społecznych. Stąd wyłania się pytanie, jakie funkcje pełnią wartości w społeczeństwie. Jest to pytanie o wartości jako zmienne niezależne. $Z$ drugiej strony wartości nie są konstruktami myślowymi, nie są abstraktami, lecz są standardami podlegającymi uwarunkowaniom miejsca i czasu. Stąd powstaje pytanie o wartości jako zmienne zależne, czyli pytanie o przemiany wartości, zakres tych przemian i ich przyczyny"40.

Drugi z rozważnych aspektów wartościowania - metodologiczny - pojawia się zazwyczaj przy okazji opisu zagadnień merytorycznych (co ma miejsce w niniejszym opracowaniu), lecz stanowi także nurt empirycznej metodologii. Antoni Sułek, analizując rozwój „socjologii ankietowej” w kontekście doświadczeń społecznych, podkreśla sukces „metody ankietowej” w powiązaniu z konwencją uprawiania socjologii. Koncentracja badań empirycznych na problematyce świadomości społecznej implikuje dominację technik ankietowych ${ }^{41}$. Mimo słabości warsztatowych „socjologii ankietowej” wobec zmian rzeczywistości społeczno-politycznej, jak też wątpliwości natury teoretycznej i epistemologicznej, ostatecznie uznaje ankietę za cenne narzędzie pracy socjologów ${ }^{42}$. J. Szymczyk przedstawia te zagadnienia w kontekście zasad „uprawomocnienia

38 S. Nowak, Metodologia badań społecznych, PWN, Warszawa 1985, s. 90.

39 J. Szymczyk, W świecie ludzkich kreacji. Stanisława Ossowskiego koncepcja rzeczywistości społecznej, Wydawnictwo KUL, Lublin 2005, s. 186-187.

40 J. Szymczyk, Pomiędzy marzeniami..., s. 140-141.

41 A. Sułek, Ogród metodologii socjologicznej, Wydawnictwo Naukowe Scholar, Warszawa 2002, s. $32-34$.

42 Tamże, s. 41. 
tożsamości socjologii jako nauki”. Na kanwie omówień dorobku Stanisława Ossowskiego wskazuje nurty reorientacji metodologicznej. Podkreśla wpływ neopozytywizmu na ujęcia teoretyczne, jak też na badania terenowe i techniki zbierania danych. Stanowisko socjologów empirystów, zwłaszcza tendencję redukowania rozważań na temat zjawisk społecznych do wzorów zaczerpniętych $\mathrm{z}$ nauk przyrodniczych, w tym matematycznych, zestawia $\mathrm{z}$ koncepcją socjologii humanistycznej. Jako rodzaj zalecenia uwydatnia potrzebę dążenia do jedności podstaw teoretycznych, założeń metodologicznych i operacji badawczych ${ }^{43}$. Rozpatrując te kwestie w odniesieniu do badań wartości, w tym porównawczych, J. Szymczyk analizuje konsekwencje różnych ujęć i definicji wartości. Przywołuje wspomniane już trudności zestawiania podejść na poziomie teoretycznym i metodologicznym, ale ponadto istotne skutki - w sensie poznawczym i oceny efektów praktyki badawczej - na poziomie zgodności definicji teoretycznych i operacyjnych ${ }^{44}$. Zdaniem M. Misztal przeważająca wśród socjologów tendencja do traktowania wartości jako przekonań odnosi się bardziej do badań niż do teorii, może jednocześnie stanowić przejaw owego dążenia do większej zgodności między ustaleniami teoretycznymi i praktyką badawczą ${ }^{45}$. Adam Bartoszek zwraca uwagę na dodatkowe problemy badań, odnosząc je wprost do tematu pracy. Trudności łączy zarówno ze znaczeniem cech społeczno-zawodowych w analizie opinii, jak i z czynnikami metodologicznymi oraz interpretacją danych introspekcyjnych. Wymienia tu błędy posiadające związek $\mathrm{z}$ indywidualistyczną metodologią i praktyką typu: agregowanie danych oraz interpretowanie prostych rozkładów ilościowych w stosunku do zbiorowości, hierarchiczne ujmowanie celów, bez uwzględnienia czynników decydujących o hierarchiach wartości oraz ich zróżnicowaniu ${ }^{46}$.

\section{Badania pracy w aspekcie konstruowania skal wartości}

Poszukiwanie odpowiedzi na pytania o możliwości ustalenia tego, czy praca stanowi wartość dla jednostek i jakiego rodzaju jest to wartość, łączy się z kolejnymi problemami badań empirycznych. W tym miejscu zostaną podjęte kwestie zastosowania podziału wartości na autoteliczne (wartości-cele) oraz

${ }^{43}$ J. Szymczyk, $W$ świecie ludzkich..., s. 46-47, 51.

44 J. Szymczyk, Pomiędzy marzeniami..., s. 135.

${ }_{45}$ M. Misztal, Elementy systemu wartości wspótczesnego społeczeństwa polskiego, PWN, Warszawa 1990, s. 14.

46 A. Bartoszek, Problemy badań warunków pracy w świetle teorii oraz ocen i opinii pracowników przemysłu, w: Metodologiczne problemy badań zachowań pracowniczych, red. W. Jacher, UŚ, Katowice 1992, s. 40-44. 
instrumentalne (wartość-środki), a także analizowania systemów wartości i zasad hierarchizacji z uwzględnieniem konstruowania skal pomiarowych.

Podział wartości na autoteliczne i instrumentalne jest $\mathrm{w}$ badaniach pracy wykorzystywany w różnych kontekstach. Ujęcie autoteliczne bywa np. zestawiane w kontraście do wartości życia codziennego ${ }^{47}$ albo koncepcji pracy traktowanej jako wartość sama w sobie i sfera samorealizacji. W ujęciu instrumentalnym pracę postrzega się poprzez skutki ekonomiczne i społeczne, a punitywnym - jako przykrą konieczność życiową ${ }^{48}$. Z perspektywy praktyki badawczej użyteczne są wyjaśnienia, które odnoszą się do teorii postaw. Antonina Kłoskowska przeciwstawia wartości autoteliczne tym instrumentalnym w sferze motywacji, nie zaś funkcji. Pracę można uznać za wartość autoteliczną, gdy jednostka odczuwa zadowolenie podczas jej wykonywania: autoteliczność łączy się z doświadczeniem i percepcją, a nie z aspektami czynnościowymi i efektami ${ }^{49}$. W. Piwowarski odwołuje się natomiast do dualnej koncepcji obiektu postaw. Praca w sensie ogólnym stanowi pewną wartość społeczną ugruntowaną w celach życiowych i hierarchii wartości, dlatego sposób jej postrzegania pozostaje w relacji nadrzędności wobec znaczenia wykonywanych zajęć zarobkowych. Decyduje to o dwóch poziomach relacji jednostki względem obiektu. Przedmiot postawy może zatem pełnić podwójną funkcję: celu i instrumentu działania, co w przypadku pracy oznacza podział na pracę jako wartość (samą w sobie) i jako normę (środek do celu). Zdaniem autora o pracy jako wartości można mówić wtedy, kiedy służy bezpośredniemu zaspokajaniu potrzeby działalności produkcyjnej czy usługowej i/lub samorealizacji, a o normie - gdy są realizowane inne potrzeby, np. ekonomiczne. Te dwa rodzaje stosunku do pracy nie muszą się wykluczać, zwłaszcza wobec oczywistości funkcji dochodowej ${ }^{50}$. A. Bartoszek, analizując termin orientacje wobec pracy, również odwołuje się do założenia dotyczącego ogólnej postawy (metapostawy), która kieruje zachowaniami jednostek w pracy i jest bardziej trwała niż stosunek do konkretnej pracy. Identyfikuje się ją na podstawie wartościującego nastawienia. W ujęciach badawczych stawia się pytania o miejsce pracy w systemie wartości, co jednocześnie wpływa na analizę warunków pracy ${ }^{51}$.

Koncepcje systemu wartości oraz hierarchicznego układu czy porządkowania wartości (kryterium ważności) są zatem na gruncie socjologii przedmiotem systematycznych dyskusji. W odniesieniu do procedur budowania skal war-

${ }^{47}$ D. Dobrowolska, Wartość pracy dla jednostki w środowisku przemysłowym, Ossolineum, Wrocław 1984, s. 5.

${ }^{48}$ W. Kozek, Praca $w$ warunkach zmian rynkowych. Wybrane zagadnienia, Prywatne Policealne Studium Handlowe First Business College, Warszawa 1994, s. 31.

49 A. Kłoskowska, Socjologia kultury..., s. 200-204.

${ }^{50}$ W. Piwowarski, Postawy religijne..., s. 308-309.

${ }^{51}$ A. Bartoszek, Problemy badań..., s. 34. 
tości często podkreśla się, że badacze na ogół interesują się wieloma różnymi wartościami oraz określaniem ich znaczenia dla jednostek i grup społecznych. Chociaż stosuje się niejednakowe metody, to efektem jest zazwyczaj ustalenie jakiejś hierarchii wartości (jednej czy kilku). Brakuje jednak podstawy teoretycznej dającej prawomocność tego rodzaju postępowaniu oraz interpretacji wyników, szczególnie w zakresie wyjaśniania i przewidywania zachowań oraz opisu przemian systemów wartości ${ }^{52}$. J. Szymczyk wskazuje ponadto, że socjologowie-empirycy zwracają uwagę na hierarchię wartości, która w gruncie rzeczy stanowi tylko element ich struktury. Aprioryczne założenie hierarchicznej struktury wartości i „narzucanie” go na badaną rzeczywistość skutkuje natomiast błędami metodologicznymi. Nie zmienia to faktu, że dążenia do systematyzacji wartości pełnią istotną rolę, także w sensie praktycznym, nawet jeśli w socjologicznym ujęciu hierarchia nie przesądza o rodzaju wartości uznawanych za wyższe ${ }^{53}$.

$\mathrm{Na}$ tym tle jednym $\mathrm{z}$ kluczowych problemów badań są kwestie związane $z$ konstruowaniem zestawów niewspółmiernych wartości. Krytyczne podejście jest zazwyczaj łączone z dorobkiem S. Ossowskiego. Jego zdaniem postępowanie badawcze wymaga tu założenia, że w jednym systemie mogą współistnieć wartości różnego rodzaju i z różnych poziomów (np. uznawane i odczuwane). Należałoby także przyjąć możliwość wyodrębnienia systemów wartości poszczególnych jednostek czy grup społecznych. Nieprawidłowość polega tu poza wszystkim - na porównywaniu cech w sytuacji braku wspólnej skali czy "akcji”" ${ }^{4}$. J. Szymczyk, podkreślając wkład S. Ossowskiego w porządkowanie podstaw teoretycznych badań dotyczących wartości oraz wpływ jego poglądów na polską socjologi $e^{55}$, przybliża jednocześnie ów problem „niewspółmierności skal wartości". Pierwszy jej rodzaj odnosi do wartości uznawanych (kryterium intelektualno-poznawacze) i odczuwanych (kryterium psychiczno-emocjonalne), których ważność jest trudna do zestawienia z powodu braku wspólnej miary. Drugi rodzaj analizuje na poziomie konkurencyjności w ramach zbioru wartości odczuwanych, które mimo przynależenia do tej samej kategorii wymagają odrębnej postawy (np. kontemplacja piękna przyrody a kłopoty w pracy). Przyczyną rozbieżności może być ponadto współistnienie $\mathrm{w}$ danym środowisku społecznym niewspółmiernych skal wartości ${ }^{56}$.

Wymienione problemy w jakimś stopniu odnoszą się do większości badań poświęconych miejscu pracy w systemie wartości czy wartości pracy. Tymczasem

52 M. Misztal, Problematyka wartości w socjologii..., s. 58, 68.

53 J. Szymczyk, Odkrywanie wartości. Z problematyki socjologiczno-aksjologicznej, Polihymnia, Lublin 2004, s. 125.

${ }^{54}$ S. Ossowski, O osobliwościach nauk społecznych, PWN, Warszawa 1983, s. 123 n.

55 J. Szymczyk, Odkrywanie wartości..., s. 143-144.

56 Tenże, W świecie ludzkich kreacji..., s. 187-188. 
kategoria: wartość pracy w zasadzie nie posiada swoistej definicji. Zazwyczaj można jednak spotkać dwa ujęcia: w pierwszym przedmiotem badań jest praca jako wartość i ustala się jej miejsce w systemie wartości, a w drugim określa się ważność poszczególnych elementów czy aspektów pracy. Zwraca się przy tym uwagę na niejednorodność syndromatyczną pojęcia i problemy metodologiczne związane z ograniczeniami porównywania rezultatów badań, wynikające m.in. z konieczności analizowania poszczególnych (w tym niewspółmiernych) cech i składników ${ }^{57}$. W badaniach wartości pracy występują zatem zróżnicowane ujęcia. Jadwiga Szefer-Timoszenko i Teresa Stolorz-Raab, odwołując się do aspektów uświadamianych przez jednostki jako ważne i przesądzające o znaczeniu pracy, wyodrębniły elementy: treściowy, humanistyczny, materialny, prestiżowy, społeczny, czasowy, przestrzenny i organizacyjny ${ }^{58}$. Danuta Dobrowolska zastosowała podejście, w którym analizowała: miejsce pracy wśród wartości życia codziennego, ważność różnych jej aspektów, wartości abstrakcyjne przejawiające się w pracy. Wśród mierzonych aspektów znalazły się: warunki zewnętrzne (np. lokalowe, techniczne, czas pracy); organizacja i środowisko społeczne; szanse na przyszłość (np. stałość zatrudnienia, podnoszenie kwalifikacji, awans ${ }^{59}$. Koncepcja pracy jako wartości została natomiast wykorzystana w badaniach zespołowych Juliana Bugiela i in. Podstawą były komponenty wyczerpujące desygnat pojęcia wartości pracy i kategorie określające pracę, czyli: cechy i treść, aspekt społeczny, aspiracje z nią związane ${ }^{60}$. W projekcie badacze wyróżnili funkcje pracy: twórcza (tworzenie wartości, np. duchowych, kulturowych, cywilizacyjnych), samorealizacyjna (rozwój osobowy, nadawanie życiu sensu i treści), dochodowa, społeczna (na rzecz dobra wspólnego, budowanie więzi), gospodarcza, socjalizacyjna. Czynniki jednostkowe ujęli zaś w formie warunków: ekonomicznych, technicznych i fizycznych środowiska pracy, organizacyjnych, społecznych, rozwoju zawodowego i awansu, współuczestnictwa w zarządzaniu, potrzeb, emocji, motywacji i postaw ${ }^{61}$. W badaniach porównawczych (Wielka Brytania, Grecja) zestawiono z kolei trzydzieści siedem wartości (itemów), składających się w zasadzie na całościową charakterystykę sytuacji pracy jednostek ${ }^{62}$. Współcześnie cechy pracy bywają łączone z czynnikami jej podejmowania, wśród których dominują względy: materialne, egzystencjalne,

57 J. Bugiel, M. Burkiewicz, L.H. Haber, W. Pawnik, Praca jako wartość w świadomości załogi przedsiębiorstwa przemysłowego. Raport z badań, AGH, Kraków 1990, s. 33.

58 J. Szefer-Timoszenko, T. Stolorz-Raab, Praca jako wartość, w: Wartość pracy zawodowej, red. J. Szefer-Timoszenko, Wydawnictwo UŚ, Katowice 1978, s. 9, 13.

59 D. Dobrowolska, Wartość pracy..., s. 38, 40-41.

60 J. Bugiel, M. Burkiewicz, L.H. Haber, W. Pawnik, Praca jako wartość..., s. 34.

61 Tamże, s. 40-42.

62 A. Furnham, K.V. Petride, I. Tsaousis, K. Pappas, D. Garrod, A Cross-Cultural Investigation Into the Relationships Between Personality Traits and Work Values, „The Journal of Psychology” 2005, t. 139 , nr 1, s. 12-13. 
społeczne (kontakty z innymi, pozycja społeczna), kreatywne, samorealizacyjne (samodoskonalenie, kariera, pokonywanie słabości) i hedonistyczno-ludyczne (praca jako źródło radości) ${ }^{63}$. W badaniach własnych wartość pracy ujęto $\mathrm{w}$ aspekcie aksjologicznym, stąd rozumienie jest bliskie określeniom: doniosłość, ważność czy znaczenie. Sfera pracy jest traktowana w kategoriach działania służącego realizacji innych wartości, ale ze względu na posiadanie treści i znaczenia dla jednostek także jako przedmiot indywidualnej refleksji i oceny, zatem: wartośśc ${ }^{64}$. W kategoriach operacyjnych oznaczało to m.in. ustalanie: miejsca pracy wśród celów życiowych, kluczowych wymiarów czy funkcji pracy oraz łączonych z nią celów, ważności poszczególnych aspektów pracy i oceny stopnia ich realizacji w obecnie wykonywanej pracy, czynników zadowolenia z pracy.

\section{Analiza wyników badań własnych}

Wyniki międzynarodowych badań porównawczych European Values Study (EVS) i licznych sondaży systematycznie wykazują, iż na całym świecie dominującą pozycję ma wartość rodziny, i na tym tle Polacy są typowi. W latach 1990 i 1999 także praca okazała się jedną z najważniejszych sfer życia (78\%), zaraz po rodzinie ${ }^{65}$. Odnosząc się do współczesnych eksploracji systemów wartości, J. Szymczyk podkreśla znaczenie „orientacji na rodzinę, zajmującej w świadomości Polaków niezmiennie czołowe miejsce ${ }^{66}$.Zdaniem Danuty Walczak-Duraj, wyniki badań (CBOS: 2015, 2018) potwierdzają podobną tendencję w przypadku pracy: dla zdecydowanej większości respondentów $(77,4 \%)$ stanowi ona istotną wartość, a ponadto utrzymuje się zadowolenie z wykonywanej pracy, zwłaszcza pod względem merytorycznym ${ }^{67}$. Mimo wykazywanych w badaniach ogólnie wysokich pozycji pracy wśród cenionych wartości, interpretacja tego obrazu jest złożona. W jakiejś mierze rezultaty zależą od definicji i operacjonalizacji kategorii: praca i wartości, jak również od sposobów ujmowania tych zagadnień. Na podstawie badań CBOS można np. stwierdzić wzrost zadowolenia z pracy, dokładnie jednak „z przebiegu pracy zawodowej”. Udział osób zadowolonych

${ }^{63}$ F. Bylok, U. Swadźba, D. Walczak-Duraj, Praca i konsumpcja..., s. 123.

64 Por. J. Jezior, Wartość pracy..., s. 49.

65 M. Sikorska, Zmiany postaw Polaków wobec pracy. Lęk przed bezrobociem i samorealizacja, w: Polacy wśród Europejczyków. Wartości społeczeństwa polskiego na tle innych krajów europejskich, red. A. Jasińska-Kania, M. Marody, Wydawnictwo Naukowe Scholar, Warszawa 2002, s. 25 n.

66 J. Szymczyk, Socjologiczne rozumienie..., s. 40. Autor odwołuje się m.in. do raportów CBOS (2017, 2019).

67 D. Walczak-Duraj, Miejsce pracy w systemie wartości..., s. 99-100. 
wyniósł odpowiednio: $1997-48 \%$; $2002-51 \%$; $2011-61 \%$; $2019-71 \%{ }^{68}$. Według raportu dotyczącego najważniejszych celów (pragnień) życiowych tym razem „aspiracje” związane z życiem rodzinnym pozostawały niezmiennie na wysokim poziomie (1998 - 69\%, 2018 - 64\%), zaś te łączone z pracą wyrażano rzadziej (34\% i 25\%) ${ }^{69}$. W sondażu (2018), w którym badani oceniali „różne obszary aktywności ludzi”, były one z kolei odmienne sformułowane w zależności od kontekstu. Opinie dotyczyły zatem tego, „czemu obecnie najgorliwiej poświęcają się ludzie" znani respondentom, spotykani na co dzień. I w tym wypadku najczęściej wskazano pracę (70\%), przed życiem rodzinnym (61\%) i zdobywaniem pieniędzy (31\%). W stosunku do siebie respondenci mieli określić rodzaj działalności, który „stanowi obecnie treść (...) życia codziennego”, czemu poświęcają "najwięcej czasu i energii”. W odpowiedziach dominowało życie rodzinne (72\%), praca (53\%) i ochrona zdrowia $(28 \%)^{70}$. W badaniach, w których polecono wskazać wartości uważane „za najważniejsze w swoim codziennym życiu”, pierwszą lokatę zajęło „szczęście rodzinne” (2019 - 80\%), natomiast „praca zawodowa” - siódmą $(36 \%)^{71}$.

W projekcie z 1996 r. skierowanym do mieszkańców regionu środkowo-wschodniej Polski (MR) wartości były ujmowane w wymiarze świadomościowym - deklarowanych pragnień (wartości upragnionych dla własnego dziecka). Dominujące okazały się: mądrość, zdobywanie wiedzy (47,4\%); wiara w Boga, religijność (46,6\%); dostatek, zabezpieczenie materialne (36,9\%); szczęśliwe życie małżeńsko-rodzinne (33,8\%). Pracowitość i rzetelność w pracy zajęła dopiero dziewiątą pozycję $(12,6 \%)^{72}$. Interpretując te wyniki, L. Dyczewski podkreślił rangę kluczowych wartości i jednocześnie wyraźne zdystansowanie pozostałych. W komentarzu metodologicznym zwrócił też uwagę na problemy badań systemów wartości, w tym zestawiania wartości, które należą do różnych sfer życia i są innego rodzaju: sensu życia (ostateczne) i życiowe (docelowe, bezpośrednio osiągalne), uroczyste i codzienne ${ }^{73}$. W kolejnych projektach (badania własne) zadanie opisu cenionych wartości i lokowania na tym tle pracy zostało zmodyfikowane. Podobnie jak wcześniej wartości ujęto w aspekcie świadomościowym - jako przekonania, ale pytanie wskaźnikowe dotyczyło najważniejszych celów i dążeń życiowych (tabela 1), inny był też zestaw kategorii i sposób określenia sfery pracy.

${ }^{68}$ Zadowolenie z życia. Komunikat z badań, CBOS 2020, nr 2, s. 5.

69 Aspiracje Polaków w latach 1998, 2008, 2018. Komunikat z badań, CBOS 2018, nr 148, s. 4.

70 Codzienna aktywność Polaków. Autoportret i obraz środowiska społecznego w latach 1988-2018, Komunikat badań, CBOS 2018, nr 164, s. 2-3.

${ }^{71}$ Rodzina - jej znaczenie i rozumienie. Komunikat z badań, CBOS 2019, nr 22, s. 3.

72 W pytaniu podano siedemnaście kategorii, z ograniczeniem możliwych wyborów do trzech.

73 L. Dyczewski, Społeczno-kulturowe..., s. 149 n. 
Tabela 1. Cele i dążenia życiowe (dane w \%)

\begin{tabular}{|c|c|c|c|c|}
\hline \multirow{2}{*}{ Kategorie odpowiedzi } & $\begin{array}{c}\text { Pracownicy } \\
\text { najemni }\end{array}$ & \multicolumn{3}{|c|}{$\begin{array}{c}\text { Osoby prowadzące własną } \\
\text { działalność gospodarczą }\end{array}$} \\
\cline { 2 - 5 } & 2004 & $2002-2003$ & 2011 & 2019 \\
\cline { 2 - 5 } & $\mathrm{N}=359$ & $\mathrm{~N}=736$ & $\mathrm{~N}=605$ & $\mathrm{~N}=342$ \\
\hline Udane życie małżeńskie, rodzinne & 71,0 & 68,5 & 54,8 & 51,5 \\
\hline Spokojne życie, bez pośpiechu i stresów & 32,9 & 36,8 & 54,5 & 43,6 \\
\hline Utrzymanie dobrej kondycji zdrowotnej & 32,3 & 34,7 & 31,0 & 31,9 \\
\hline Życie zgodne z własnymi przekonaniami & 20,1 & 17,3 & 20,6 & 29,8 \\
\hline Odpowiedni poziom materialny życia & 21,5 & 30,8 & 22,2 & 26,0 \\
\hline Osiągnięcie wiedzy i umiejętności zawodowych & 9,8 & 11,7 & 15,0 & 21,9 \\
\hline Możliwość podróżowania, zwiedzania innych krajów & 13,7 & 12,6 & 16,0 & 18,7 \\
\hline Posiadanie grona dobrych przyjaciół & 17,0 & 16,7 & 17,6 & 16,1 \\
\hline Poczucie, że jest się potrzebnym dla innych & 25,4 & 16,3 & 17,0 & 15,5 \\
\hline Posiadanie własnego mieszkania, domu & 16,2 & 9,1 & 14,0 & 13,2 \\
\hline Możliwość wpływu na sprawy polityczne, gospodarcze & 0,6 & 1,9 & 4,1 & 6,4 \\
\hline Osiągnięcie wysokiej pozycji zawodowej & 4,7 & 4,6 & 6,7 & 5,3 \\
\hline Wykonywanie interesującej pracy & 12,5 & 9,8 & $5,9^{*}$ & $4,1^{\star}$ \\
\hline Wyjazd na stałe za granicę & 0,3 & 1,8 & 0,3 & 1,2 \\
\hline Inne odpowiedzi & 1,4 & 0,5 & 1,1 & 1,2 \\
\hline Możliwość dalszego kształcenia zawodowego & 5,3 & 3,4 & $* *$ & $*$ \\
\hline
\end{tabular}

Dane nie sumują się do 100\%, ponieważ można było wybrać do trzech kategorii (2011 i 2019 - do czterech); nie uwzględniono braków danych; ${ }^{*}$ posiadanie dobrej pracy; ${ }^{*}$ kategoria nie wystąpiła w pytaniu.

Źródło: opracowanie na podstawie badań własnych.

Mimo upływu lat, na przestrzeni których realizowano projekty i zróżnicowania badanych zbiorowości, zbiory kluczowych wartości były zbliżone: udane życie małżeńskie i rodzinne, spokój i brak stresów, zdrowie, bezpieczeństwo ekonomiczne, wierność zasadom, więzi społeczne. Uzyskane wyniki wpisują się zatem w rezultaty wielu badań, zwłaszcza w odniesieniu do rodziny, ale zwracają uwagę konsekwentnie niskie lokaty pracy. Przyczyny miejsca pracy w tych ogólnych strukturach mogą mieć charakter merytoryczny i metodologiczny. Pierwsza kwestia wiąże się z przemianami społecznymi, których przejawy obserwuje się także w zakresie postaw wobec pracy. J. Mariański podkreśla ewoluowanie tych postaw w kierunku traktowania pracy jako środka osiągania innych celów, jakkolwiek nie oznacza to utraty wartości. Praca przestaje być postrzegana jako jedyny czy główny cel życia, będąc podporządkowana etosowi samorealizacji ${ }^{74}$. D. Walczak-Duraj łączy złożone przewartościowania w sferze pracy m.in. z oddziaływaniem logiki współczesnej gospodarki rynkowej i przemianami

\footnotetext{
${ }^{74}$ J. Mariański, Etos pracy bezrobotnych..., s. 76.
} 
form zatrudnienia, ze zjawiskiem „praktycznego indywidualizmu” czy problemami kształtowania standardów etycznych ${ }^{75}$. Jeżeli chodzi o wpływ rozwiązań badawczych i technicznych, to tego rodzaju mechanizmy zazwyczaj występują w badaniach sondażowych. Warto zauważyć, że formuła pytania zmierzała do zmniejszenia niewspółmierności dzięki przesunięciu akcentu na wartości życia codziennego, lecz zbiór kategorii był obszerny i zróżnicowany jakościowo, a respondenci musieli odpowiadać w warunkach ograniczonej liczby wyborów. Przypadek pracy można by zatem uznać za efekt sytuacji pomiaru. Niemniej inne wartości uzyskały znaczącą frekwencję, co osłabia tego rodzaju konkluzję. Ostatecznie przemawia to na rzecz interpretacji, zgodnie z którą praca nie jest postrzegana jako cel życiowy, niezależnie jak się ją określa - interesująca czy dobra. Nie umniejsza to wielowymiarowego znaczenia tej sfery, czego dowodzą całościowo ujęte wyniki badań. Pracy przypisywano zasadniczą rolę w życiu, niekiedy dominującą (osoby prowadzące własną działalność gospodarczą), i to nie tylko ze względu na funkcję ekonomiczną, bowiem dostrzegano w niej możliwości realizacji ważnych celów życiowych, w tym samorealizacyjnych. Można było też stwierdzić interioryzację normy: zdecydowana większość badanych wyraziła opinię, że warto jest być pracowitym, ponieważ wcześniej czy później przyniesie to korzyści (PN - 54,8\%; P1 - 71,5\%; P2 - 89,8\%) ${ }^{76}$. O wartości pracy świadczy także deklaracja, że nie zrezygnowano by z jej wykonywania nawet w warunkach pełnego zabezpieczenia ekonomicznego (PN - 53,5\%; P1 - 64,3\%; P2 - 73,1\%). Co istotne, poglądy te wykazywały stosunkowo mały zakres asocjacji ze zmiennymi społeczno-demograficznymi czy zawodowymi. Wreszcie, mimo niezaspokojenia części oczekiwań łączonych z pracą, przeważało pozytywne nastawienie, co wyraża np. deklarowane zadowolenie z obecnej pracy (MR 90\%; PN - 85,2\%; P1 - 86,6\%; P2 - 82,5\%; P3 - 87,4\%).

Wielowymiarowość znaczenia pracy potwierdzają ponadto wyniki analizy jej koncepcji, ukazujące jednocześnie przypisywane funkcje i relacje z innymi sferami życia (tabela 2). W projektach $\mathrm{z}$ lat 1996-2004 zastosowano pytanie z tzw. kafeterią, z możliwością wyboru do trzech kategorii. Zdecydowaną większość wypowiedzi wypełniały obrazy pracy jako: źródła utrzymania, realizacji zobowiązania wobec rodziny, obszaru samorealizacji. W kolejnych projektach (P2, P3) zastosowano pytanie, w którym te same kategorie podano w formie stwierdzeń opisujących, czym jest dla badanych osób praca. Respondenci mieli za zadanie ustosunkować się do nich, posługując się pięciostopniową skalą akceptacji: od 1 - „zdecydowanie nie” do 5 - „zdecydowanie tak”. Kwestie upływu czasu, zróżnicowania prób badawczych i pytań ponownie nie przyniosły

${ }^{75}$ D. Walczak-Duraj, Procesy przewartościowania pracy - główne uwarunkowania i tendencje, w: Przemiany pracy, postaw i ról zawodowych, red. D. Walczak-Duraj, Wydawnictwo UŁ, Łódź 2011, s. $42 \mathrm{n}$.

${ }^{76}$ To i następne omówione pytanie nie wystąpiło w badaniach: 1996 (MR) i 2019 (P3). 
spektakularnej odmienności rezultatów. Zmiana poziomu pomiaru umożliwiła jednak poznanie opinii na temat każdego z wymiarów pracy, co dało inną jej ogólną charakterystykę, zwłaszcza pod względem społecznym i moralnym. Potwierdziły się też przypuszczenia dotyczące oczywistości funkcji ekonomicznej i tego, że jej obecność nie przesądza o wyłącznie instrumentalnym podejściu wobec pracy.

Tabela 2. Postrzeganie pracy - funkcje i relacje z innymi sferami życia (dane w \%)

\begin{tabular}{|c|c|c|c|c|c|}
\hline \multirow{2}{*}{ Stwierdzenia: praca jest... } & $\begin{array}{c}\text { Mieszkańcy } \\
\text { regionu }\end{array}$ & $\begin{array}{c}\text { Pracownicy } \\
\text { najemni }\end{array}$ & \multicolumn{3}{|c|}{$\begin{array}{c}\text { Osoby prowadzące własną } \\
\text { działalność gospodarczą }\end{array}$} \\
\cline { 2 - 6 } & 1996 & 2004 & $2002-2003$ & 2011 & 2019 \\
\cline { 2 - 6 } & $\mathrm{N}=800$ & $\mathrm{~N}=359$ & $\mathrm{~N}=739$ & $\mathrm{~N}=611$ & $\mathrm{~N}=342$ \\
\hline Źródłem zarobku, dochodu & 74,1 & 93,3 & 91,3 & $82,2(96,7)$ & $86,6(98,8)$ \\
\hline Obowiązkiem wobec rodziny & 49,9 & 45,7 & 57,0 & $56,3(86,0)$ & $44,5(75,5)$ \\
\hline Przyjemnością, radością & 29,0 & 33,2 & 32,9 & $21,1(63,3)$ & $25,4(74,8)$ \\
\hline Koniecznością życiową & 30,6 & $\star$ & $*$ & $46,5(80,4)$ & $36,3(71,1)$ \\
\hline Nadaje życiu sens & 28,8 & 29,5 & 26,7 & $41,6(74,5)$ & $25,7(62,0)$ \\
\hline Zobowiązaniem moralnym & 4,9 & 3,6 & 4,3 & $24,5(51,1)$ & $22,2(51,1)$ \\
\hline Obowiązkiem wobec społeczeństwa & 6,0 & 7,5 & 5,4 & $18,6(45,8)$ & $15,5(35,4)$ \\
\hline Powinnością religijną & 5,4 & 0,3 & 1,0 & $7,8(14,6)$ & $5,6(11,7)$ \\
\hline Ciężarem, czynnością męczącą & 3,3 & 7,0 & 3,5 & $2,5(11,1)$ & $1,2(11,1)$ \\
\hline Inne & 1,9 & 3,1 & 2,3 & $*$ & $*$ \\
\hline
\end{tabular}

Dane w kolumnach nie sumują się do 100\%: od drugiej do czwartej - można było wybrać do trzech kategorii, w piątej i szóstej - podano tylko odpowiedzi „zdecydowanie tak” (w nawiasach łącznie z „raczej tak”); nie uwzględniono braków danych; ${ }^{\star}$ kategorie nie wystąpiły w pytaniach.

Źródło: opracowanie na podstawie badań własnych.

Formuła pytania (P2, P3) dała ponadto możliwość uchwycenia osi organizujących sposoby postrzegania pracy, tworząc bardziej spójny interpretacyjnie obraz. Wykonano analizę polegającą na redukcji wymiarów metodą głównych składowych: $\mathrm{PCA}^{77}$, w obu projektach uzyskując zbliżoną strukturalizację zmiennych. Na pierwszy plan wysuwa się koncepcja zobowiązania przede wszystkim wobec rodziny, ale też: społecznego, moralnego, religijnego. Odmienny typ buduje się wokół indywidualnych potrzeb i nastawienia wobec pracy, opierając się na wymiarze samorealizacyjnym i sensotwórczym, w opozycji do ujęcia punitywnego. Trzecią składową organizuje wymiar ekonomiczny: podstaw utrzymania i konieczności życiowej.

77 Analiza metodą głównych składowych z rotacją Varimax (na podstawie zmiennych pięciostopniowych, w wersji standaryzowanej). Miary testu K-M-O: w P2 było to 0,727; w P3 0,722 (p < 0,001). Przyjęty graniczny poziom wartości bezwzględnej ładunków czynnikowych: 0,3. 
Kryteria wartościowania pracy, ale też relacje między postawami wobec pracy (w sensie ogólnym) i stosunkiem do konkretnej pracy można uchwycić na podstawie wyobrażeń na temat cech i warunków wykonywanej pracy (tabela 3). W badaniach mieszkańców regionu forma pytania (wielokrotnego wyboru) w jakieś mierze spowodowała silną selekcję cech „dobrej pracy”, uwydatniając tylko te kluczowe: dochód, atmosferę międzyludzką, zgodność z zawodem, bezpieczeństwo zatrudnienia, małą szkodliwość. W kolejnych projektach struktury preferencji okazały się podobne, lecz ponownie wniosek odnosi się zasadniczo do aspektów dominujących. Można by zatem uznać, że występuje zbieżność obu poziomów postaw, głównie w wymiarze: ekonomicznym, samorealizacyjnym i więziotwórczym. Wzmocnieniem tendencji jest jej obecność także w sytuacji zastosowania innego poziomu pomiaru. W PN i P1 cechy dobrej pracy były oceniane według pięciostopniowej skali ważności (od 1 - „zupełnie nieważna” do 5 - „bardzo ważna”). Zdecydowana większość z nich uzyskała powyżej 75-80\% pozytywnych not, zaś zarobek ponad $97 \%{ }^{78}$. Kryteria decydujące o koncepcjach pracy tworzą więc nie tylko złożony i zróżnicowany zbiór, lecz - uwzględniając przypisywaną im ważność - współwystępują też w charakterystykach dokonywanych przez poszczególne jednostki. W P2 i P3 zadano pytanie (wielokrotnego wyboru) na temat cech „satysfakcjonującej pracy”. Przeważały aspekty: ekonomiczny, autonomii, społeczny, organizacyjny, rozwoju zawodowego.

Tabela 3. Cechy dobrej/satysfakcjonującej pracy - zestawienie porównawcze (dane w \%)

\begin{tabular}{|c|c|c|c|c|c|}
\hline \multirow{2}{*}{ Kategorie odpowiedzi } & $\begin{array}{c}\text { Mieszkańcy } \\
\text { regionu }\end{array}$ & $\begin{array}{c}\text { Pracownicy } \\
\text { najemni }\end{array}$ & \multicolumn{3}{|c|}{$\begin{array}{c}\text { Osoby prowadzące własną } \\
\text { działalność gospodarczą }\end{array}$} \\
\cline { 2 - 6 } & 1996 & 2004 & $2002-2003$ & 2011 & 2019 \\
\cline { 2 - 6 } & $\mathrm{N}=802$ & $\mathrm{~N}=355$ & $\mathrm{~N}=727$ & $\mathrm{~N}=611$ & $\mathrm{~N}=342$ \\
\hline Możliwość dobrego zarobku & 53,6 & $70,3(98,0)$ & $69,6(97,1)$ & 55,3 & 71,3 \\
\hline Możliwość samodzielnego działania & 8,1 & $53,0(90,9)$ & $59,2(91,0)$ & 61,4 & 68,7 \\
\hline Dobra atmosfera wśród pracowników & 31,5 & $82,3(97,5)$ & $64,0(92,7)$ & 34,2 & 40,4 \\
\hline Możliwość podnoszenia kwalifikacji & 5,5 & $48,4(92,0)$ & $42,7(77,9)$ & 23,7 & 31,3 \\
\hline Możliwość spotykania się z ludźmi & 9,2 & $39,2(78,0)$ & $41,3(78,1)$ & 27,7 & 28,1 \\
\hline Dobra organizacja pracy & 12,0 & $81,1(97,2)$ & $73,9(95,6)$ & 33,4 & 27,8 \\
\hline Interesujące, urozmaicone zajęcia & 9,0 & $27,3(71,5)$ & $28,4(70,1)$ & 17,2 & 26,0 \\
\hline Mała stresowość & 6,7 & $60,6(86,6)$ & $51,1(82,6)$ & 24,1 & 20,8 \\
\hline Zgodność z wyuczonym zawodem & 30,8 & $22,2(52,8)$ & $20,9(42,3)$ & 11,9 & 10,8 \\
\hline Pewność utrzymania miejsca pracy & 26,4 & $71,7(93,2)$ & $65,5(89,8)$ & 20,1 & 10,5 \\
\hline Możliwość awansu & 4,5 & $34,6(80,6)$ & $31,6(68,6)$ & 7,0 & 7,9 \\
\hline Zdrowe warunki pracy & 21,9 & $63,0(91,5)$ & $57,8(88,6)$ & 7,2 & 6,7 \\
\hline Stałe godziny pracy & 10,1 & $44,9(81,4)$ & $25,5(59,0)$ & 11,3 & 5,8 \\
\hline
\end{tabular}

${ }^{78}$ Zob. J. Jezior, Społeczno-kulturowe..., s. 209-230. 


\begin{tabular}{|c|c|c|c|c|c|}
\hline \multirow{2}{*}{ Kategorie odpowiedzi } & $\begin{array}{c}\text { Mieszkańcy } \\
\text { regionu }\end{array}$ & $\begin{array}{c}\text { Pracownicy } \\
\text { najemni }\end{array}$ & \multicolumn{2}{|c|}{$\begin{array}{c}\text { Osoby prowadzące własną } \\
\text { działalność gospodarczą }\end{array}$} \\
\cline { 2 - 7 } & 1996 & 2004 & $2002-2003$ & 2011 & 2019 \\
\cline { 2 - 7 } & $\mathrm{N}=802$ & $\mathrm{~N}=355$ & $\mathrm{~N}=727$ & $\mathrm{~N}=611$ & $\mathrm{~N}=342$ \\
\hline Dobre wyposażenie techniczne & 6,0 & $49,7(90,9)$ & $48,4(88,6)$ & 8,3 & 5,3 \\
\hline Odpowiednia ocena pracowników & 2,9 & $56,0(89,2)$ & $39,5(78,3)$ & 6,2 & 4,7 \\
\hline Poczucie osobistej satysfakcji & $\star$ & $70,5(95,2)$ & $64,1(92,3)$ & $\star$ & $*$ \\
\hline
\end{tabular}

Dane w kolumnach nie sumują się do 100\%: w drugiej i trzeciej podano tylko odsetki „bardzo ważna cecha” (w nawiasach łącznie z „raczej ważna”); w pierwszej można było wybrać do trzech kategorii, w pozostałych do czterech; nie uwzględniono braków danych; *kategoria nie wystąpiła w pytaniu.

Źródło: opracowanie na podstawie badań własnych.

Zmiany budowy pytania, które wynikały z dążenia do większej zgodności konstruktów teoretycznych i operacjonalizacji, w pewnym stopniu potwierdziły podatność rezultatów na te działania. Przykładem jest skontrastowanie frekwencji (MR) z jednej strony, z drugiej zaś niemal zupełne wypełnienie charakterystyki oczekiwań przez wszystkie podane aspekty (PN, P1). W przypadku opisu dobrej czy satysfakcjonującej pracy uruchamiają się jednak dodatkowe trudności porównań. Większość oczekiwań wykazywała powiązania z cechami respondentów, zwłaszcza społeczno-zawodowymi, a pod tym względem zbiorowości różniły się istotnie (np. wykształcenie, status zatrudnienia). W rezultacie dopiero analizy dwu-i wielozmiennowe, których celem było m.in. uchwycenie czynników wyjaśniających systematycznie pojawiające się przekonania, a także zestawienie charakterystyki postaw wobec pracy (ujęcie ogólne) i wobec konkretnej pracy, przyniosły znaczące spostrzeżenia. Po pierwsze, dominujące koncepcje okazały się uniwersalne: uzyskano symboliczne wręcz asocjacje i to głównie z cechami demograficznymi. Przy czym równoczesne oddziaływanie licznych czynników kształtujących sytuację pracy osłabiało zależności. Wystąpiła jednak znana $\mathrm{z}$ badań socjologicznych reguła, iż wraz ze wzrostem poziomu wykształcenia coraz częściej pojawiała się orientacja samorealizacyjna i wewnętrzne elementy motywacyjne, w tym aspekty samodzielności, wykonywania interesujących zajęć, rozwoju kwalifikacji. Po drugie, spójność poglądów na temat koncepcji pracy (np. wymiary, funkcje) i wykonywanej pracy (dobrej, satysfakcjonującej) objęła tylko wybrane cechy, jak już podkreślano - te dominujące w skali zbiorowości. Po trzecie, stwierdzono stosunkowo niewielki zakres powiązań między preferencjami dotyczącymi ważnych aspektów i ocenami poziomu ich realizacji w obecnej pracy (P2, P3) ${ }^{79}$. Implikuje to pytanie o relacje na linii - przekonania i podejmowane działania zawodowe, ekonomiczne. Niemniej asocjacje objęły charakterystyczne kwestie: samorealizację i więzi międzyludzkie. Szczególny

${ }^{79}$ Zob. Taż, Satysfakcjonująca praca $w$ warunkach indywidualnej działalności gospodarczej, „Konteksty Społeczne” 2019, t. 7, nr 2(14), s. 53 n. 
przypadek stanowi zgodność z zawodem: osoby wskazujące to kryterium niemal dwukrotnie częściej (niż pozostałe) wysoko oceniły ów aspekt we własnej pracy $(\mathrm{P} 2: \mathrm{V}=0,26 ; \mathrm{P} 3: \mathrm{V}=0,31)^{80}$. Po czwarte, $\mathrm{w}$ zasadzie nie stwierdzono zależności między wartościowaniem pracy (np. wymiary, cechy) i zadowoleniem z pracy. Dopiero opinie na temat stopnia realizacji określonych aspektów (kryteria jak w tabeli 3) wykazały takie powiązania, chociaż do wyjątków należały: stałe godziny, mała stresowość i możliwość awansu. Po wprowadzeniu zmiennych (oceny aspektów) do modelu uwarunkowań zadowolenia (zmienna binarna) okazało się, że szansę na tak rozumiany sukces istotnie zwiększa wykonywanie pracy: samodzielnej (I.S.: P2 = 1,74; P3 = 4,01) i przynoszącej wysoki zarobek (I.S.: P2 = 2,07; P3 = 2,98) ${ }^{81}$. Wreszcie, dominujące orientacje - ekonomiczna i samorealizacyjna - okazały się niejednorodne. Postrzeganie pracy poprzez funkcje ekonomiczne miało charakter nastawienia merytokratycznego lub tzw. bytowego, zorientowanego na utrzymanie źródeł dochodu. Orientacja samorealizacyjna była równie wielowymiarowa: zawierała motywację autoteliczną, ale też profesjonalną, łączyła się z potrzebami osobistego rozwoju i autonomii. $\mathrm{W}$ powiązaniu z cechami społeczno-zawodowymi te „suborientacje” odgrywały kluczową rolę w procesie wyjaśniania różnic w zakresie sytuacji pracy.

\section{Podsumowanie}

W opracowaniu omówiono wybrane problemy badań socjologicznych poświęconych miejscu pracy w systemie wartości, z uwzględnieniem aspektu teoretycznego i metodologicznego oraz praktyki badawczej. Uwaga została skoncentrowana na trudnościach wynikających z licznych ujęć koncepcyjnych, połączenia wieloznacznych terminów: praca i wartości, stosowania różnych definicji pojęciowych i operacyjnych, a ponadto na warunkach poznawczych i technicznych badań ilościowych (tu: sondażowych). Kryteriami decydującymi o zakresie rozważań, z konieczności ujętymi fragmentarycznie, była obecność dyskutowanych zagadnień z jednej strony w koncepcjach badań własnych, co umożliwiało egzemplifikację, $\mathrm{z}$ drugiej natomiast - w dorobku naukowo-badawczym J. Szymczyka.

Opisane projekty badawcze, mimo wspólnych elementów koncepcyjnych i replikacji wskaźników, nie spełniają wymogów badań porównawczych: różni je czas realizacji i kontekst społeczny, rodzaj prób i charakterystyka zbiorowości, zakres problematyki, techniki zbierania danych i konstrukcje pytań kwestionariuszowych. Wymienione powody nie dawały podstaw ekstrapolowania wyników, zaś wąski wycinek prezentowanych analiz ograniczał interpretację problemów miejsca

${ }^{80}$ Podano V Cramera, przy $\mathrm{p}<0,001(\mathrm{P} 2, \mathrm{P} 3)$.

81 I.S. - iloraz szans, przy p < 0,001. Zastosowano domyślną (zwykłą) metodę wprowadzania. 
pracy w systemie wartości i kryteriów decydujących o jej znaczeniu dla jednostek. Rezultaty badań wykazały jednak wiele zbieżności, co dotyczy przekonań na temat kluczowych wymiarów i funkcji pracy oraz cech satysfakcjonującej pracy, jak również relacji między postawami wobec pracy w ogólnym ujęciu i wobec konkretnej pracy. Przemiany dokonujące się na rynku pracy, w tym w zakresie form zatrudnienia, wydają się nie naruszać znacząco owych postaw nadrzędnych i pozytywnych nastawień. Należy jednak podkreślić, że te konkluzje odnoszą się do zestawień zbiorczych i deskrypcji na poziomie zbiorowości. Tymczasem szczegółowe analizy potwierdziły dyferencjację koncepcji pracy jako sfery życia, podobnie jak kryteriów określania jej wartości i czynników satysfakcji, a ostatecznie podstaw kształtowania sytuacji pracy jednostek i sposobów jej postrzegania.

$\mathrm{W}$ rozważaniach uwydatniano dylematy związane z prowadzeniem badań ilościowych poświęconych zagadnieniu miejsca pracy w systemie wartości. Stąd też obok kwestii merytorycznych znalazły się elementy obserwacji „metod w działaniu". Uwagi krytyczne, kierowane także w stosunku do badań własnych, miały na celu nie tyle umniejszenie roli poznawczej i aplikacyjnej tego rodzaju eksploracji, ile zilustrowanie niełatwych decyzji badawczych oraz ich konsekwencji. Jako rodzaj konstatacji posłuży zatem pogląd J. Szymczyka, często wyrażany w jego twórczości. Analizując problemy teoretyczne i metodologiczne w zakresie tematyki wartości, podkreślał, że nie powinny one zniechęcać socjologów do prowadzenia pracy badawczej, a co najwyżej skłaniać do pogłębionej refleksji dotyczącej koncepcji wartości oraz precyzowania pojęć, klasyfikowania wartości i hierarchizacji. Umożliwi to uzyskanie odpowiedniości między pojęciami wyjściowymi i językiem empirii, jak również doskonalenie warunków porównywania „badań nad wartościami”"

\section{Bibliografia}

Aspiracje Polaków w latach 1998, 2008, 2018. Komunikat z badań, CBOS 2018, nr 148, https://www. cbos.pl/SPISKOM.POL/2018/K_148_18.PDF (dostęp: 9.10.2021).

Bartoszek A., Problemy badań warunków pracy w świetle teorii oraz ocen i opinii pracowników przemysłu, w: Metodologiczne problemy badań zachowań pracowniczych, red. W. Jacher, UŚ, Katowice 1992, s. 23-47.

Borkowska S., Równowaga między praca a życiem pozazawodowym, „Acta Universitatis Lodziensis. Folia Oeconomica" 2010, nr 240, s. 5-44.

Bugiel J., Burkiewicz M., Haber L.H., Pawnik W., Praca jako wartość w świadomości załogi przedsiębiorstwa przemysłowego. Raport z badań, AGH, Kraków 1990.

Bylok F., Swadźba U., Walczak-Duraj D., Praca i konsumpcja w perspektywie tworzenia ładu aksjonormatywnego, Wydawnictwo Naukowe "Śląsk", Katowice 2017.

Carland J.W., Hoy F., Boulton W.R., Carland J.A.C., Differentiating Entrepreneurs from Small Business Owners. A Conceptualization, w: Entrepreneurship. Concepts, Theory and Perspective,

82 J. Szymczyk, Pomiędzy marzeniami..., s. 135. 
red. Á. Cuervo, D. Ribeiro, S. Roig, Springer-Verlag, Berlin 2007, s. 73-81, https://www.uv.es/ catedrabancajauveg/docs/LibroCuervoRibeiroRoigENG (dostęp 3.07.2021).

Codzienna aktywność Polaków. Autoportret i obraz środowiska społecznego w latach 1988-2018, Komunikat z badań, CBOS 2018, nr 164, https://www.cbos.pl/SPISKOM.POL/2018/K_164_18. PDF (dostęp: 8.09.2021).

Dobrowolska D., Wartość pracy dla jednostki w środowisku przemysłowym, Ossolineum, Wrocław 1984.

Dyczewski L., Kultura polska w procesie przemian, TN KUL, Lublin 1993.

Dyczewski L., Społeczno-kulturowe czynniki rozwoju regionu środkowo-wschodniej Polski i Euroregionu Bug, Norbertinum, Lublin 1997.

Furnham A., Petride K.V., Tsaousis I., Pappas K., Garrod D., A Cross-Cultural Investigation Into the Relationships Between Personality Traits and Work Values, "The Journal of Psychology" 2005, t. 139, nr 1, s. 5-32, DOI: 10.3200/JRLP.139.1.5-32.

Giermanowska E., Mrozowicki A., Róg-IInicka J., Socjologia pracy w Polsce. Społeczno-gospodarcze i polityczne problemy instytucjonalizacji subdyscypliny, "Przegląd Socjologiczny”, 2019, t. 68, nr 3, s. 11-41, DOI: 10.26485/PS/2019/68.3/1.

Janicka K., Sytuacja pracy a struktura społeczna. W poszukiwaniu nowego wymiaru pozycji społeczno-zawodowej, Wydawnictwo IFiS PAN, Warszawa 1997.

Januszek H., Sikora J., Socjologia pracy, Wydawnictwo Akademii Ekonomicznej, Poznań 1998.

Jezior J., Satysfakcjonująca praca w warunkach indywidualnej działalności gospodarczej, „Konteksty Społeczne" 2019, t. 7, nr 2(14), s. 46-66, DOI: 10.17951/ks.2019.7.2.46-66.

Jezior J., Społeczno-kulturowe i rynkowe czynniki kształtowania sytuacji pracy przedsiębiorców. Na podstawie badań małych firm w województwie lubelskim, Wydawnictwo UMCS, Lublin 2009.

Jezior J., Wartość pracy. Studium socjologiczne na podstawie badań mieszkańców regionu środkowowschodniej Polski, Wydawnictwo UMCS, Lublin 2005.

Kiersztyn A., Niepewność zatrudnienia młodych dorosłych. Analiza sekwencji karier zawodowych, „Studia BAS” 2020, nr 2(62), s. 73-90.

Kłoskowska A., Socjologia kultury, PWN, Warszawa 1983.

Konecki K., Praca w koncepcji socjologii interakcjonistycznej, ,'Studia Socjologiczne” 1988, nr 1(108), s. 225-245.

Kozek W., Praca w warunkach zmian rynkowych. Wybrane zagadnienia, Prywatne Policealne Studium Handlowe First Business College, Warszawa 1994.

Lee S.M., Peterson S.J., Culture, Entrepreneurial Orientation, and Global Competitiveness. „Journal of World Business" 2000, t. 35, nr 4, s. 401-416, DOI: 10.1016/S1090-9516(00)00045-6.

Mariański J., Etos pracy bezrobotnych (raport z badań empirycznych), TN KUL, Lublin 1994.

Misztal M., Elementy systemu wartości współczesnego społeczeństwa polskiego, PWN, Warszawa 1990.

Misztal M., Problematyka wartości w socjologii, PWN, Warszawa 1980.

Nowak S., Metodologia badań społecznych, PWN, Warszawa 1985.

Ossowski S., O osobliwościach nauk społecznych, PWN, Warszawa 1983.

Piwowarski W., Postawy religijne a postawy wobec pracy, w: Człowiek i praca. Studia i szkice wokółchrześcijańskiej koncepcji pracy, red. J. Wołkowski, Instytut Wydawniczy "Pax", Warszawa 1979, s. 305-330.

Praca na własny rachunek - determinanty i implikacje, red. E. Kryńska, IPiSS, Warszawa 2007.

Rodzina - jej znaczenie i rozumienie. Komunikat z badań, CBOS 2019, nr 22, https://cbos.pl/SPISKOM. POL/2019/K_022_19.PDF (dostęp: 31.08.2021).

Sikorska M., Zmiany postaw Polaków wobec pracy. Lęk przed bezrobociem i samorealizacja, w: Polacy wśród Europejczyków. Wartości społeczeństwa polskiego na tle innych krajów europejskich, red. A. Jasińska-Kania, M. Marody, Wydawnictwo Naukowe Scholar, Warszawa 2002.

Sułek A., Ogród metodologii socjologicznej, Wydawnictwo Naukowe Scholar, Warszawa 2002.

Swadźba U., Śląski etos pracy. Studium socjologiczne, Wydawnictwo UŚ, Katowice 2001.

Szczepański J., Uwagi o przedmiocie i zadaniach socjologii pracy, w: Jak pracuje człowiek. Z badań polskich psychologów, socjologów i ekonomistów, red. B. Biegeleisen-Żelazowski, T. Tomaszewski, A. Sarapata, J. Rosner, Książka i Wiedza, Warszawa 1961, s. 169-184. 
Szefer-Timoszenko J., Stolorz-Raab T., Praca jako wartość, w: Wartość pracy zawodowej, red. J. Szefer-Timoszenko, Wydawnictwo UŚ, Katowice 1978, s. 9-35.

Szylko-Skoczny M., Zmiany w modelu pracy , Studia Ekonomiczne” 2014, nr 167, s. 174-183.

Szymczyk J., Odkrywanie wartości. Z problematyki socjologiczno-aksjologicznej, Polihymnia, Lublin 2004.

Szymczyk J., Pomiędzy marzeniami a faktami. Szkice socjologiczne, Norbertinum, Lublin 2005.

Szymczyk J., Socjologiczne rozumienie wartości w aspekcie relacjonistycznym, "Zeszyty Naukowe KUL" 2019, t. 62, nr 3(247), s. 34-54, DOI: 10.31743/zn.2019.62.3.03.

Szymczyk J., W świecie ludzkich kreacji. Stanisława Ossowskiego koncepcja rzeczywistości społecznej, Wydawnictwo KUL, Lublin 2005.

Świda-Zięba H., Wartości egzystencjalne młodzieży lat dziewięćdziesiątych, Wydawnictwo UW, Warszawa 1999.

Thurik A.R., Carree M.A., van Stel A.J., Audretsch D.B., Does Self-Employment Reduce Unemployment? "Journal of Business Venturing" 2007, t. 23, nr 6, s. 673-686, DOI: 10.1016/j.jbusvent.2008.01.007.

Urbaniak B., Polityka państwa wobec osób starszych na rynku pracy, „Problemy Polityki Społecznej. Studia i Dyskusje" 2016, nr 34(3), s. 71-88.

Walczak-Duraj D., Miejsce pracy w systemie wartości. Wyzwania wynikajace z rozwoju technologii cyfrowych, ,Zeszyty Naukowe KUL", 2019 t. 62, nr 4(248), s. 91-115, DOI: 10.31743/zn.2019.62.4.05.

Walczak-Duraj D., Procesy przewartościowania pracy - główne uwarunkowania i tendencje, w: Przemiany pracy, postaw i ról zawodowych, red. D. Walczak-Duraj, Wydawnictwo UŁ, Łódź 2011, s. 29-51.

Wiśniewski J., Istota samozatrudnienia, „Studia z Zakresu Prawa, Administracji i Zarządzania” 2013, t. 3, s. 35-59.

Zadowolenie zż̇cia. Komunikat z badań, CBOS 2020, nr 2, https://cbos.pl/SPISKOM.POL/2020/K_002_ 20.PDF (dostęp: 8.09.2021).

\section{Streszczenie}

$\mathrm{W}$ artykule przedstawiono wybrane problemy badań socjologicznych poświęconych miejscu pracy $\mathrm{w}$ systemie wartości. Rozważane zagadnienia zostały ujęte w trzech aspektach: teoretycznym, metodologicznym i empirycznym. Kryteriami doboru omawianych kwestii były z jednej strony ujęcia koncepcyjne i metodologiczne zastosowane $\mathrm{w}$ badaniach własnych, $\mathrm{z}$ drugiej natomiast omówienia tych zagadnień w dorobku naukowo-badawczym Jana Szymczyka. Szczególne znaczenie mają poglądy tego autora w zakresie teorii wartości, krytyczne refleksje dotyczące koncepcji wartości i zasad ich definiowania na gruncie socjologii, jak również metodologii realizowanych badań. Materiał badawczy, który wykorzystano w celu egzemplifikacji, pochodzi z projektów badawczych zrealizowanych w latach 1996-2019 na terenie województwa lubelskiego.

Słowa kluczowe: praca, sytuacja pracy, wartości, system wartości, badania ilościowe

\section{Selected Issues in Studies on the Position of Work in the Value System}

\section{Summary}

The article discusses a selection issues in the sociological research on the position of work in the system of values. The examined issues are dealt with in three aspects: theoretical, methodological and empirical. The selection of issues for analysis is determined by the conceptual and methodological approach applied by Jan Szymczyk, which has to do with the fact that Szymczyk's own analyses of the issues at hand constitute a significant part of his own research legacy. In my article, special im- 
portance is attached to Szymczyk's views on the theory of values, his critical reflections concerning the concept of values, principles of defining values is sociology and on the methodological aspects of the related research. The research material employed is taken from selected research projects carried out in between 1996 and 2019 in the Lublin Voivodship.

Key words: work, position of work, values, system of values, quantitative studies 